\title{
Revisiting Solar Photovoltaic Roadmap of Tropical Malaysia: Past, Present and Future
}

\author{
Hedzlin Zainuddin ${ }^{1 *}$, Hazman Raziq Salikin ${ }^{1}$, Sulaiman Shaari ${ }^{1}$, \\ Mohamad Zhafran Hussin ${ }^{2}$ and Ardin Manja ${ }^{1}$ \\ ${ }^{1}$ Faculty of Applied Sciences, Universiti Teknologi MARA, 40450 Shah Alam, Selangor, Malaysia \\ ${ }^{2}$ Faculty of Electrical Engineering, Universiti Teknologi MARA Cawangan Johor, Kampus Pasir Gudang, \\ 81750 Masai, Johor, Malaysia
}

\begin{abstract}
Environmental issues and economic factors such as emission of Greenhouse Gases (GHGs), fossil fuel depletion and fluctuation of oil prices are also the reason behind the utilization of sunlight as a source of energy. Even though with the spread of unprecedented pandemic of COVID 19, the industry of solar photovoltaic (PV) is surviving at a very promising rate compared to the oil industry. Malaysia has a high potential to be successful at harnessing solar energy as this country is located within the equatorial region. The government of Malaysia (GoM) introduced various policies, acts and incentives programs for the purpose of increasing this country's potential to harness solar energy. Along with the efforts, goals and aims have also been set as a benchmark to measure Malaysia's success in utilizing sunlight as an energy source. This study reviews the roadmap programs executed by GoM to elucidate the significant roles played in the development of solar PV starting from a few pilot projects in1980s until present. The roadmap focuses on incentive programs namely Feed-in Tariff (FiT), Net Energy Metering (NEM), Self-Consumption

ARTICLE INFO

Article history:

Received: 13 January 2021

Accepted: 13 April 2021

Published: 31 July 2021

DOI: https://doi.org/10.47836/pjst.29.3.25

$\overline{\text { E-mail addresses: }}$

hedz1506@uitm.edu.my (Hedzlin Zainuddin)

hazman_raziq@yahoo.com (Hazman Raziq Salikin)

solarman1001@gmail.com (Sulaiman Shaari)

mzhafran@uitm.edu.my (Mohamad Zhafran Hussin)

ardinmanja92@gmail.com (Ardin Manja)

* Corresponding author Scheme (SELCO), Large Solar Scale (LSS), Supply Agreement with Renewable Energy (SARE) and 'Peer-to-Peer' (P2P), which complement all the projects and solar PV applications in Malaysia. The contributing result of this roadmap is the highlights on the continuous solar PV programs stimulated by GoM, the identification and effort to improve the less performing GoM incentive
\end{abstract}


programs combined with the positive responses from communities and industries, have laid a strong platform to forecast a promising future of solar PV industry in Malaysia.

Keywords: Feed-in tarif; large solar scale; net energy metering; peer-to-peer; self-consumption scheme

\section{INTRODUCTION}

Malaysia's electricity demand is forecasted to rise by 35\% in 2030 from 14007 MW in 2008. The rise in demand for electricity calls for the utilization of renewable energy as an alternative to non-renewable energy sources. Malaysia is blessed with an abundance of renewable energy sources, particularly sunlight. The average annual sum of global horizontal irradiation (GHI) of Malaysia is between $1400 \mathrm{kWh} / \mathrm{m}^{2}$ to $1900 \mathrm{kWh} / \mathrm{m}^{2}$ (Samaiden, 2020). On top of that, Malaysia receives on average 12 hours of sunlight daily (Aziz et al., 2016; Bakh et al., 2014). Harnessing solar energy for source of sustainable energy can be done by utilising solar photovoltaic (PV) technology (Pacudan, 2018). Through proper policy and encouraging incentives, solar energy potential to become this country's source of sustainable energy can be enhanced (Pacudan, 2016).

Various initiatives have been carried out by the GoM in order to maximize solar energy harnesses (Hussin et al., 2012). In 2000, Fifth Fuel Policy 2000 which included renewable energy as the fifth fuel in the energy mix was introduced during the $8^{\text {th }}$ Malaysia Plan (Bakh et al., 2014; Maulud \& Saidi, 2012; Petinrin \& Shaaban, 2015). Renewable Energy Act 2011 (Act 725) was introduced by the GoM to implement a special tariff for enhancing the generation and utilization of renewable energy in Malaysia. Feed-in Tariff (FiT) was the tariff highlighted in the act (Sustainable Energy Development Authority, 2011) and was the foundation policy for solar PV in Malaysia (ASEAN Centre for Energy, 2016). The incentive programs were taken very seriously by GoM, hence the incentive programs were introduced under the Ninth and Tenth Malaysia Plan (2011-2015). The programs have stimulated PV systems installations by providing benefits to the applicants.

Four more major programs have been employed consecutively as an effort to harness renewable energy sources in Malaysia namely Net Energy Metering (NEM), Self-Consumption Scheme (SELCO), Large Solar Scale (LSS), Supply Agreement with Renewable Energy (SARE) and 'Peer-to-Peer' (P2P). Besides these five significant and recent programs, there are many more programs successfully executed by GoM in the past; but this study is limited to discuss in-depth of these five programs.

The objective of this paper is to trace the roadmap of solar PV in Malaysia. The roadmap is presented in a timeline, which has been divided into three different categories which are past, present and future. The significance of this study is to forecast the future development of solar PV in Malaysia, acknowledge and encourage the application of best practice mechanisms in promoting solar PV and learn the drawbacks of the less performing incentive programs related to solar PV development. 


\section{ROADMAP OF SOLAR PHOTOVOLTAIC (PV)}

The roadmap includes the development of solar PV in Malaysia, incentives carried out for facilitating the utilization of solar PV technologies, and any events related to solar PV in Malaysia.

\section{Past}

In the 1980s, solar PV applications were first used for rural electrification and to power telecommunications infrastructure. The PV system used was off-grid photovoltaic (OGPV), which required minimum maintenance due to its simple operation (Almaktar et al., 2015). In order to provide electrical energy to rural communities in Malaysia, more rural electrification programs were accepted by the Ministry of Rural Development. Under the initiatives of the Ministry of Energy, Water and Communications (MEWC) and support from the Japanese New Energy and Industrial Technology Development Organization, a pilot project of solar PV was implemented in Marak Parak, Sabah in the year 1995 (Almaktar et al., 2015; Solangi et al., 2011). The project implemented was an OGPV system consisted of 1887 solar panels (Dalimin, 2018).

Chua et al. (2011) mentioned that the Grid-Connected Photovoltaic (GCPV) in Malaysia was first installed in July 1998 in Universiti Tenaga Nasional, having 3.15 kWp capacity. Following the event, British Petroleum (BP) Malaysia installed $8 \mathrm{kWp}$ GCPV at BP petrol station and Universiti Kebangsaan Malaysia (UKM) installed 5.5 kWp GCPV at Solar Energy Research Park. These were three of six pilot projects of GCPV in Malaysia aimed to minimize consumer's electricity bills by reducing the amount of electricity imported from the grid (Almaktar et al., 2015; Ruoss, 2007).

Ruoss (2007) stated that the first house to have Building Integrated Photovoltaic (BIPV) installed was the home of Tenaga Nasional Berhad (TNB) senior officer's house in Port Dickson with $3.15 \mathrm{kWp}$ capacity in August 2000. The second BIPV was installed at a house in Shah Alam in November 2000 with a capacity of $3.24 \mathrm{kWp}$. In November 2001, another BIPV with a capacity of $2.8 \mathrm{kWp}$ was installed in Subang Jaya (Mekhilef et al., 2012; Ruoss, 2007). These three BIPV home installations were the continuity of the GCPV

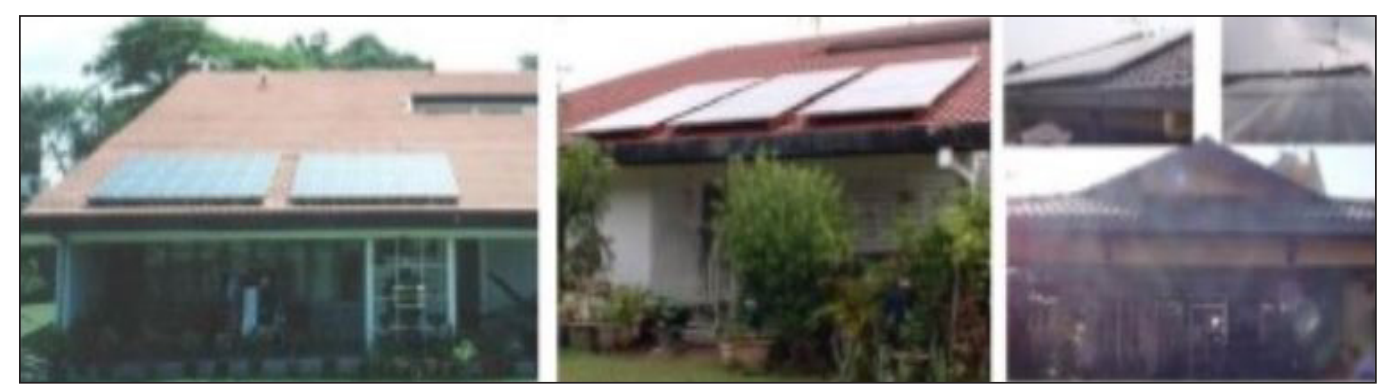

Figure 1. Port Dickson, Shah Alam and Subang Jaya first home installed BIPV (Haris et al., 2003) 
pilot project in Universiti Tenaga Nasional, BP petrol station and Solar Energy Research Institute (SERI). Figure 1 shows the image of the first three home installed BIPV system.

Under the $8^{\text {th }}$ Malaysia Plan (2001-2005), Fifth Fuel Policy was implemented in 2000 to introduce renewable energy as a part of the energy mix (Chua \& Oh, 2012). The implementation of this policy was driven by the increase of oil price and depletion of fossil fuel (Maulud \& Saidi, 2012; Petinrin \& Shaaban, 2015). Small Renewable Energy Program (SREP) was launched in 2001 with an aim to make renewable energy sources contribute to $5 \%$ of electricity generation (Malaysian Building Integrated Photovoltaic Project Team, 2006). Unfortunately, only $0.3 \%$ of electricity was contributed from renewable energy sources by 2005 (Spicher et al., n.d).

Along with the 9th Malaysia Plan (2006-2010), a Five-year project called Malaysian Building Integrated Photovoltaic (MBIPV) was launched on 25 July 2005. The MBIPV project aimed to provide an encouraging environment of BIPV application in Malaysia so that solar energy uptake can be intensified (Almaktar et al., 2015; Petinrin \& Shaaban, 2015). Consequently, dependency on fossil fuels as a source of energy can be reduced. Under MBIPV, a program Suria1000 was launched on 22nd June 2007 as a financial incentive to aid the MBIPV project (Mekhilef et al., 2012).

\section{Present}

National Renewable Energy Policy and Action Plan (NREPAP) was launched in April 2011. This policy was also included in the $10^{\text {th }}$ Malaysia Plan (2011-2015) (Almaktar et al., 2015). Under the $10^{\text {th }}$ Malaysia Plan, FiT was introduced as an incentive to increase renewable energy utilization (Chua et al., 2011). The mechanism of FiT is investors are rewarded upon electricity generation. The FiT was quite desirable because the program was a business opportunity as it encourages the export of electricity generated to the grid. The benefits of FiT are guaranteed payment, consumers have access to the grid and the creation of jobs (Pacudan, 2018). According to Bakh et al. (2014), 8\% of yearly degression is very discouraging to investors. Table 1 shows the FiT rates after the yearly $8 \%$ degression rate and also the details of bonus FiT rates for Solar PV installations ( Sustainable Energy Development Authority, 2012):

$11^{\text {th }}$ Malaysia Plan covers the time span of 2016 until 2020. In 2017, FiT was no longer an incentive program for solar PV but limited to biomass, wind and small hydro (Chen et al., 2018). Three new incentive programs were introduced under the $11^{\text {th }}$ Malaysia Plan which are NEM, SELCO and LSS (Ahmad, 2019a).

Net Energy Metering (NEM). NEM was introduced to replace FiT. The concept of NEM is consumer utilise the electricity generated from solar PV and export the excess energy generated to the grid to be sold to utility (Sustainable Energy Development Authority, 2017). 
Table 1

FiT rates for solar PV (21 years from FiT commencement date) ( Sustainable Energy Development Authority, 2012)

\begin{tabular}{lccc}
\hline \multirow{2}{*}{ Basic rates according to installed capacity } & \multicolumn{3}{c}{ FiT rate (RM) } \\
\cline { 2 - 4 } & 2012 & 2013 & 2014 \\
\hline Installed capacity up to and including 4 kWp & 1.23 & 1.1316 & 1.0411 \\
Installed capacity above 4 kWp and up to and including 24 kWp & 1.20 & 1.1040 & 1.0157 \\
Installed capacity above $24 \mathrm{kWp}$ and up to and including 72 kWp & 1.18 & 1.0856 & 0.9988 \\
Installed capacity above 72 kWp and up to and including 1 MWp & 1.14 & 1.0488 & 0.9649 \\
Installed capacity above 1 MWp and up to and including 10 MWp & 0.95 & 0.8740 & 0.8041 \\
Installed capacity above 10 MWp and up to and including 30 MWp & 0.85 & 0.7820 & 0.7194 \\
\hline Bonus FiT rates according to the following criteria (one or more) & 2012 & 2013 & 2014 \\
\hline Use as installation in buildings or building structures & +0.2600 & +0.2392 & +0.2201 \\
Use as building materials & +0.2500 & +0.2300 & +0.2116 \\
Use of locally manufactured or assembled solar PV modules & +0.0300 & +0.0276 & +0.0254 \\
Use of locally manufactured or assembled solar PV inverters & +0.0100 & +0.0092 & +0.0085 \\
\hline
\end{tabular}

Instead of being paid for gross electricity generated as in FiT, consumers are paid based on the net energy generated (Razali et al., 2019). However, due to its poor financial return of RM $0.31 / \mathrm{kWh}$ for low voltage PV (below $1 \mathrm{kV}$ ), NEM that was initially introduced in 2016 failed miserably (Sustainable Energy Development Authority, 2020). To fix the flaw of NEM, the GoM introduced a new NEM in January 2019 in which excess energy is exported to the grid on a one-on-one offset basis (same gazetted tariff, GT). The mechanism of the new NEM is calculated based on Net Charge Amount (NCA). NCA is expressed as Equation 1 (Ahmad, 2019b):

$$
N C A=(z \times G T)-(y \times G T)
$$

Whereby,

$\mathrm{z}=$ energy imported

$\mathrm{y}=$ energy exported

Application of solar PV under NEM is open to broader types of consumer, which are domestic, commercial, agricultural and industrial consumer. The cumulative net metered rooftop solar capacity, increased by 7.8 times from the first three years of the new version of NEM implementation (The Malay Mail, 2020). A study was also conducted to compare the previous and present NEM. The study found that the new NEM is more cost saving for most large and medium consumers excluding small scale consumers (Razali et al., 2019). Figure 2 shows the significant increase in cumulative net metered rooftop solar capacity after 11 months of new NEM implementation (Bhambhani, 2020). 


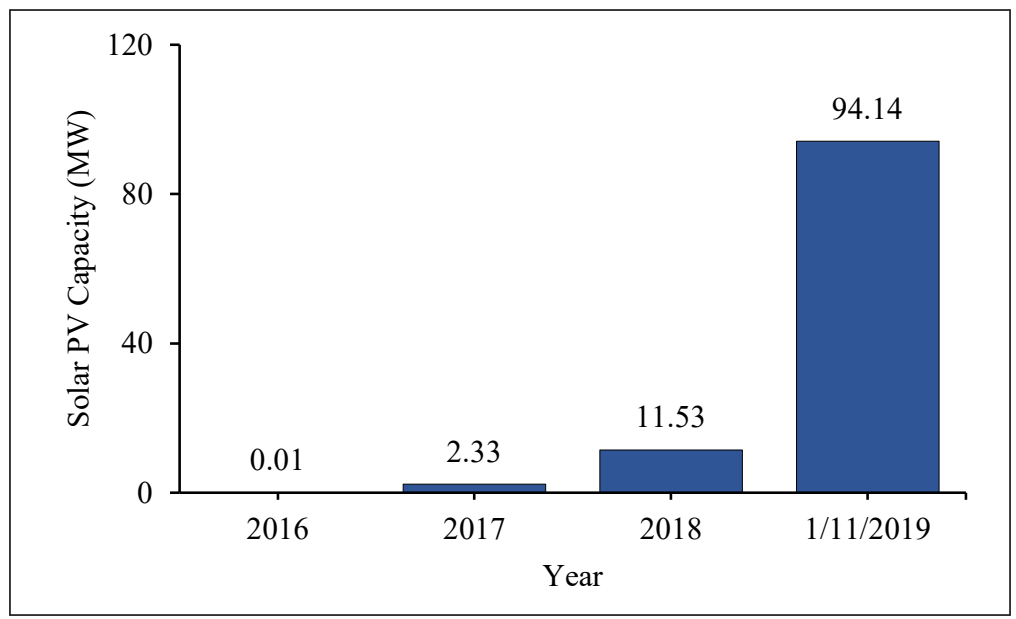

Figure 2. Cumulative net metered rooftop solar PV capacity in Malaysia (Bhambhani, 2020)

Self-Consumption (SELCO). Self-consumption (SELCO) is a scheme in which consumers generate electricity from solar PV for their own consumption that cannot be exported to the grid (Ahmad, 2019b; Chen et al., 2018). Solar PV installed under the SELCO scheme can be on-grid or off-grid. If it is on-grid, the capacity limit is $75 \%$ of the maximum demand of the existing installation, meanwhile for off-grid type there is no capacity limit. According to Chiew (2019), excess energy generated under the SELCO scheme goes to waste. The participants for the SELCO scheme are limited to only individual and commercial premise consumers (Ahmad, 2019b). Under the SELCO scheme, a private generating license is compulsory for the system beyond $72 \mathrm{~kW}$ (Sustainable Energy Development Authority, 2017). By the end of 2018, the total capacity recorded under the SELCO scheme was 60 MW (Chen et al., 2018).

Large Solar Scale (LSS). Large Solar Scale (LSS) is a bidding program to lower the levelized cost of energy (LCOE) for LSS PV plant development (Samaiden, 2020). This incentive program is for a local company with a minimum of $51 \%$ equity interest. Chen et al. (2018) stated that besides NEM, LSS is also reported to be the main driver of solar PV markets in Malaysia contributing to gigawatt worth of solar potential in Malaysia. In 2016, the first LSS tender achieved an aggregate capacity of $200 \mathrm{MW}$ and $60 \mathrm{MW}$ in Peninsular Malaysia and Sabah respectively (Energy, 2019). The increased aggregate capacity of 360 MW for Peninsular Malaysia and 100 MW for Sabah was achieved in the second tender in 2017. The third LSS bidding opened in February 2019 targeted 500 MW of aggregate capacity and waiting to be commissioned in 2021. Post COVID-19 has strengthened Malaysia's solar PV industry with the announcement of the fourth LSS with a targeted capacity of one gigawatt. This fourth cycle is expected to be operating by end of 2023 ( NST Business, 2020). 
Supply Agreement with Renewable Energy (SARE). Supply Agreement with Renewable Energy (SARE) was announced by GoM on $18^{\text {th }}$ October 2018 and the mechanism started on the $1^{\text {st }}$ January 2019. SARE aims to transform Malaysia's energy landscape to be greener. This act involves three parties which are prosumer, asset owner or investor and utility provider. The advantage of SARE is the zero upfront cost when installing a GCPV system. There are three types of solar solution under SARE, which are solar Power Purchase Agreement (PPA), Solar Hybrid and Solar Lease. Both Solar PPA and Solar Lease can enjoy zero upfront cost but not for a solar hybrid which requires approximately $20 \%$ contribution. These three types will also differ in terms of the contract term, solar tariff rate, installment and metering requirement (Tenaga Nasional Berhad, 2020). Nevertheless, the uncertainty in the trading is still significant to study and to find ways of mitigation in strengthening the programs and making it more financially attractive.

Peer-to-peer (P2P). Peer-to-peer (P2P) energy trading is introduced by GoM to increase the momentum of the community to produce green energy. The pilot run of $\mathrm{P} 2 \mathrm{P}$ took place in November 2019 in two phases; 'Alpha run' and 'Beta run'. Malaysia is the second country in ASEAN to execute P2P after Thailand (Sustainable Energy Development Authority, 2019). P2P mechanism allows a consumer who generates green energy via NEM and has surplus energy to sell the surplus to other consumers. The consumer with the surplus of green energy is called 'prosumers'. The bridge between the prosumers and customers is the utility grid, which is the TNB grid in Peninsular Malaysia. The bridge cost has to be taken into account in calculating the economic return.

This scheme enables the prosumer to sell green energy to other consumers of higher tariff (tariff B) at an estimated profit of 10\% higher than the production cost of the green energy. On the other hand, the consumer can enjoy an estimated $11 \%$ saving from this trade. Since the program is still in the pilot run stage, a reliable forecast of the economic return of this program is still debated. One of the drawbacks is on the untraded energy; is it a condition when the amount of surplus energy is greater than the traded energy. A pilot run involved up to 5 prosumers and up to 8 consumers employing 'regulatory sand box' was conducted in Malaysia with the involvement of multiple bodies including GoM (Sustainable Energy Development Authority, 2019).In this study, an analysis of the result from the pilot run was conducted and Figure 3 shows the percentage of untraded energy during the pilot run from November 2019 to June 2020. The minimum, median and maximum untraded energy were $4 \%, 18.5 \%$ and $54 \%$ respectively. It is significant to notify that maximum untraded energy was in March 2020 during the Movement Control Order (MCO) due to the unprecedented pandemic COVID-19 in Malaysia, where the majority of industries, which represents the consumers were shut down. This is one of the identified drawbacks of this program, which the untraded energy is a bonus to the utility company and not pleasant to the prosumers. 


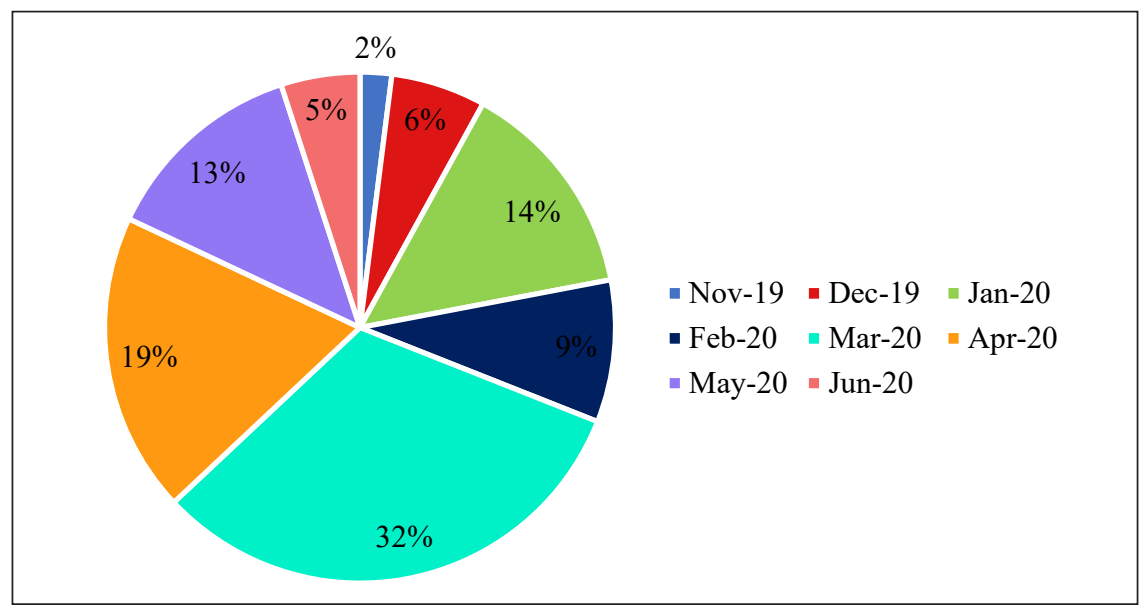

Figure 3. Percentage of untraded energy during P2P pilot run from November 2019 to June 2020

\section{Future}

The way forward of the Solar PV roadmap is forecasted to be very promising when the GoM has positioned two solar PV initiatives under the Ministry of Energy, Science, Technology and Environment Malaysia (MESTECC) in the 'The eleventh Malaysia Plan' (RMK11). The two initiatives are extending access to basic infrastructure in providing electricity by applying solar PV together with micro and pico hydro in the remote area, and ensuring solar PV contribution in renewable energy electricity generation by executing big scale program (LSS) and net energy metering (Kementerian Hal Ehwal Ekonomi, 2018). Even though RMK 11 has just ended, the GoM announcement of the target to achieve $20 \%$ of renewable energy contribution in the energy mix by the year 2025 continues to keep the solar PV industry at high momentum (Choong, 2019). Hence, Malaysia is also said to harness solar power up to $17075 \mathrm{MW}$ solar capacity by the year 2030. Consequently, this will contribute to $11.4 \%$ of the energy mix in Malaysia (Bhambhani, 2016). Figure 4 shows the Malaysia PV target from 2020 until 2030. The effort of GoM in keeping the future of solar PV has also proven with the new initiative of the Renewable Energy Transition Roadmap 2035 (RETR), which will help in strategizing to achieve $20 \%$ of renewable energy contribution in the energy mix by the year of 2025 (Kementerian Tenaga dan Sumber Asli, 2021).

The trend that portrays the bright future of solar PV as a promising sector is also observed when one of the GoM programs, which is LSS4 has attracted 138 bidders. This program of LSS4 as described in the previous section will eventually create job opportunities for approximately 12, 000 people (Yee, 2021).

Furthermore, one of the major and dominant players of energy providers in Malaysia, Tenaga Nasional Berhad (TNB) is also seen to be progressing very fast through their 


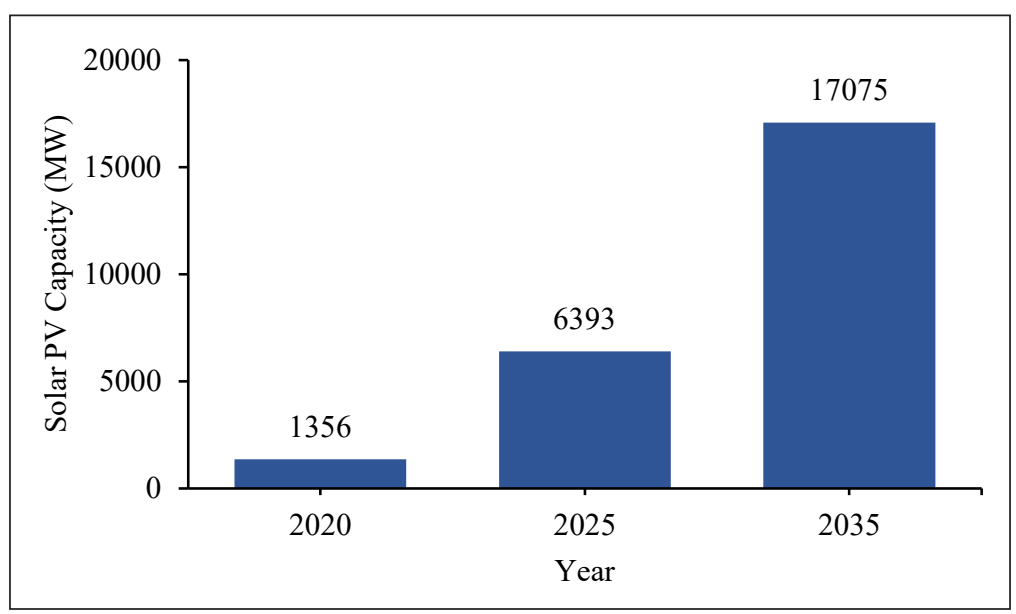

Figure 4. Malaysia Solar PV Capacity Target (Bhambhani, 2016)

investment and involvement in the Solar PV sector. The GoM initiatives together with the positive acceptance of the industry players depict and interpret the bright future of solar $\mathrm{PV}$ in Malaysia.

\section{CONCLUSION}

Malaysia has a high potential to succeed in harnessing solar energy due to its location that provides almost consistent high solar irradiation all year round with slight monthly variation. Environmental issues and economic factors should be the main driver for harnessing solar energy because harnessing unlimited energy can reduce dependency on non-renewable energy sources such as fossil fuel and yet provide a worthy financial return to investors. The GoM has been doing a great job in continuously upgrading flawed incentive programs to maximize this country's potential to harness solar energy. Finally, the most effective program would be the one that provides the highest financial return to its investor. The solar PV road map in Malaysia has witnessed the success of solar PV development and proven the role of the GoM in keeping the solar PV momentum to become a promising energy sector in Malaysia.

\section{ACKNOWLEDGMENTS}

The authors express gratitude to GoM for funding this research under 600-IRMI/FRGS 5/3 (446/2019) and 600-IRMI/FRGS 5/3 (083/2019).

\section{REFERENCES}

Ahmad, A. (2019a). Briefing by the Sustainable Energy Development Authority. Sustainable Energy Development Authority (SEDA) Malaysia. Retrieved mJuly 8, 2020, from http://www.massa.net.my/ mimos/ 
Ahmad, A. (2019b). Briefing on the new NEM, Introduction to self-consumption (SELCO) and RPVI directory application. Retrieved July 8, 2020, from http://www.seda.gov.my/download/presentation-materials/

Almaktar, M., Rahman, H. A., Hassan, M. Y., \& Omar, W. Z. W. (2015). Photovoltaic technology in Malaysia: Past, present, and future plan. International Journal of Sustainable Energy, 34(2), 128-140. https://doi. org/10.1080/14786451.2013.852198

Asean Centre for Energy. (2016). Levelized cost of electricity of selected renewable technologies in the ASEAN member states. In ASEAN Centre for Energy. Retrieved July 8, 2020, from https://tuewas-asia. org/wp-content/uploads/2017/05/4-ASEAN-RESP_LCOE-final-Nov-2016.pdf

Aziz, A., Dewi, P., Wahid, S. S. A., Arief, Y., \& Aziz, N. (2016). Evaluation of solar energy potential in Malaysia. Trends in Bioinformatics, 9, 35-43. https://doi.org/10.3923/tb.2016.35.43

Bakh, B., Saadatian, O., Alghoul, M., Ibrahim, Y., \& Sopian, K. (2014). Solar electricity market in Malaysia: A review of feed-in tariff policy. Environmental Progress \& Sustainable Energy, 34(2), 600-606. https:// doi.org/10.1002/ep.12023

Bhambhani, A. (2016). Net metering in Malaysia. Retrieved July, 8, 2020, from http://taiyangnews.info/ markets/net-metering-in-malaysia/.

Bhambhani, A. (2020). 108 MW: Malaysia's net metered PV capacity till Nov 2019. Retrieved July, 8, 2020, from http://taiyangnews.info/markets/108-mw-malaysias-net-metered-pv-capacity-till-nov-2019/.

Chen, W., Han, T. W., Damiri, N. A., \& Zaki, N. H. M. . (2018). National survey report of PV power applications in Malaysia 2018. Retrieved July, 8, 2020, from https://iea-pvps.org/wp-content/uploads/2020/01/ NSR_Malaysia_2018.pdf

Chiew, S. (2019). Types of solar power systems in Malaysia. Retrieved July, 8, 2020, from https://solarvest. my/2018/08/15/types-solar-power-systems/

Choong, J. (2019). Yeo: Malaysia aiming for 20pc renewable energy use by 2025. The Malay Mail. Retrieved July, 8, 2020, from https://www.malaymail.com/news/malaysia/2019/09/03/yeo-malaysia-aiming-for20pc-renewable-energy-use-by-2025/1786768

Chua, S. C., \& Oh, T. (2012). Solar energy outlook in Malaysia. Renewable and Sustainable Energy Reviews, 16, 564-574. https://doi.org/10.1016/j.rser.2011.08.022

Chua, S. C., Oh, T. H., \& Goh, W. W. (2011). Feed-in tariff outlook in Malaysia. Renewable and Sustainable Energy Reviews, 15(1), 705-712. https://doi.org/10.1016/j.rser.2010.09.009

Dalimin, M. (2018). Creating electricity from sunlight: Progress in science, technology and development of photovoltaics. Retrieved July, 8, 2020, from http:/www.uthm.edu.my/en/downloads/e-books/862018siri3-nohdalimin/file

Energy, G. (2019). Malaysia renewable energy 2025: Private financing key to reaching target. Retrieved July 8, 2020, from https://www.power-technology.com/comment/malaysia-needs-us8-billion-investment-toachieve-20-renewable-energy-target-by-2025/

Haris, A. H., Ismail, I. S. S., \& Penyelidikan, K. I. (2003). Building integrated photovoltaic (BIPV) applications in malaysia: Current status \& achievements. TNB Research Sdn Bhd. 
Hussin, M. Z., Hasliza, N., Yaacob, A., Zain, Z. M., Omar, A. M., \& Shaari, S. (2012). A development and challenges of grid-connected photovoltaic system in Malaysia. In 2012 IEEE Control and System Graduate Research Colloquium (pp. 191-196). IEEE Conference Publication. https://doi.org/10.1109/ ICSGRC.2012.6287160

Kementerian Hal Ehwal Ekonomi. (2018). Pelan pelaksanaan dasar: Kajian separuh penggal Rancangan Malaysia Kesebelas 2016-2020 [Implementation policy plan: The mid-term review of the eleventh Malaysia plan 2016-2020.]. Retrieved March 9, 2021, from https://www.kkmm.gov.my/pdf/KPI/PPD\%20 KSP.pdf

Kementerian Tenaga dan Sumber Asli. (2021). Bahagian tenaga boleh baharu [Renewable energy section]. Retrieved March 9, 2021, from https://www.ketsa.gov.my/ms my/MengenaiKetsa/MaklumatBahagian/ Pages/BahagianTenagaBolehBaharu.aspx

Maulud, A. L., \& Saidi, H. (2012). The Malaysian fifth fuel policy: Re-strategising the Malaysian renewable energy initiatives. Energy Policy, 48, 88-92. https://doi.org/10.1016/j.enpol.2012.06.023

Mekhilef, S., Safari, A., Mustaffa, W. E. S., Saidur, R., Omar, R., \& Younis, M. A. A. (2012). Solar energy in Malaysia: Current state and prospects. Renewable and Sustainable Energy Reviews, 16(1), 386-396. https://doi.org/10.1016/j.rser.2011.08.003

Malaysian Building Integrated Photovoltaic Project Team. (2006). Inception report: Malaysia building integrated photovoltaic technology application (MBIPV) project. Retrieved July 8, 2020, from https://www. yumpu.com/en/document/read/43136959/inception-report-malaysia-building-integrated-mbipv-project

NST Business. (2020). Malaysia opens RM4 bil bid for $1 \mathrm{GW}$ of solar plants. New Straits Times. Retrieved July 8, 2020, from https://www.nst.com.my/business/2020/06/598704/malaysia-opens-rm4-bil-bid-1gwsolar-plants

Pacudan, R. (2016). Road map for power market integration in the Brunei-Indonesia-Malaysia-Philippines (BIMP) Region. In Y. Li \& S. Kimura (Eds.), Achieving an integrated electricity market in Southeast Asia: Addressing the economic, technical, institutional, and geo-political barriers. ERIA Research.

Pacudan, R. (2018). Feed-in tariff vs incentivized self-consumption: Options for residential solar PV policy in Brunei Darussalam. Renewable Energy, 122, 362-374. https://doi.org/10.1016/j.renene.2018.01.102

Petinrin, J. O., \& Shaaban, M. (2015). Renewable energy for continuous energy sustainability in Malaysia. Renewable and Sustainable Energy Reviews, 50, 967-981. https://doi.org/10.1016/j.rser.2015.04.146

Razali, A., Abdullah, M. P., Hassan, M. Y., \& Hussin, F. (2019). Comparison of new and previous net energy metering (NEM) scheme in Malaysia. ELEKTRIKA-Journal of Electrical Engineering, 18, 36-42. https:// doi.org/10.11113/elektrika.v18n1.141

Ruoss, D. (2007). Equatorial sunshine: The Malaysia BIPV programme - Renewable energy world. Retrieved July 1, 2020, from http://www.renewableenergyworld.com/articles/print/volume-10/issue-1/solar-energy/ equatorial-sunshine-the-malaysia-bipv-programme-51560.html

Samaiden. (2020). Large scale solar (LSS). Retrieved July 1, 2020, from https://samaiden.com.my/solarphotovoltaic/\#lss 
Sustainable Energy Development Authority. (2011). Renewable Act 2011. Retrieved July 1, 2020, from http:// www.seda.gov.my/policies/renewable-energy-act-2011/

Sustainable Energy Development Authority. (2012). SEDA Malaysia. Retrieved July 1, 2020, from http:// www.seda.gov.my/

Sustainable Energy Development Authority. (2017). National survey report of PV power applications in Malaysia. Retrieved July 1, 2020, from https://ieapvps.org/wpcontent/uploads/2020/01/National_Survey_ Report_of_PV_Power_Applications_in_Malaysia-_2017.pdf

Sustainable Energy Development Authority. (2019). Solar power: SEDA introduces P2P trading programme to encourage use of renewable energy. Retrieved July 1, 2020, from https://www.seda.gov.my/2019/10/ solar-power-seda-introduces-p2p-trading-programme-to-encourage-use-of-renewable-energy/

Sustainable Energy Development Authority. (2020). Grid parity \& displaced cost. Retrieved July 1, 2020, from https://www3.seda.gov.my/?omaneg=00010100000001010101000100001000000000000000000 $000 \& s=7$.

Solangi, K. H., Lwin, T. N. W., Rahim, N. A., Hossain, M. S., Saidur, R., \& Fayaz, H. (2011). Development of solar energy and present policies in Malaysia. In 2011 IEEE Conference on Clean Energy and Technology (CET) (pp. 115-120). IEEE Confenrence Publication. https://doi.org/10.1109/CET.2011.6041447

Spicher, S., Moellmann, J., Rajput, M., Hollauer, C., \& Oladipo, J. (n.d). Solar energy potential of Malaysia: A technological potential assessment with policy recommendations. Retrieved July 8, 2020, from https:// scholar.google.com/scholar?q=related:TR51fDb1zSkJ:scholar.google.com/\&scioq=Spicher, + S., + Moellm ann,+J.,+Rajput,+M.,+Hollauer,+C.,+\%26+Oladipo,+J\&hl=en\&as_sdt=0,5

Tenaga Nasional Berhad. (2020). Supply agreement with renewable energy. Retrieved July 8, 2020, from https://www.tnbx.com.my/sare

The Malay Mail. (2020). SEDA strengthened renewable energy growth in 2019. The Malay Mail. Retrieved July 8, 2020, from https://www.malaymail.com/news/malaysia/2020/01/04/seda-strengthened-renewableenergy-growth-in-2019/1824690.

Yee, L. H. (2021). LSS4 attracts strong interest. The Star. Retrieved March 9, 2021, from https://www.thestar. com.my/business/business-news/2021/03/08/lss4-attracts-strong-interest 